\title{
Hitherto unknown morphs of two species of the genus Aphis (Homoptera: Aphididae)
}

\author{
A.V. Stekolshchikov, N.V. Leshchinskaya \& S.V. Buga
}

\begin{abstract}
Stekolshchikov, A.V., Leshchinskaya, N.V. \& Buga, S.V. 2008. Hitherto unknown morphs of two species of the genus Aphis (Homoptera: Aphididae). Zoosystematica Rossica, 17(1): 73-78.

For the first time, Aphis subviridis (Börner, 1940) and A. polygonata (Nevsky, 1929) are recorded from Byelorussia. Geographical points of species registrations are listed. The first descriptions of oviparous females and male of $A$. subviridis and male of A. polygonata are given.

A.V. Stekolshchikov, Zoological Institute, Russian Academy of Sciences, Universitetskaya nab. 1, St. Petersburg 199034, Russia.E-mail: aphids@zin.ru

N.V. Leshchinskaya \& S.V. Buga, Zoological Department, Byelorussian State University, pr. Nezavisimosti 4, Minsk 220030,Republic of Belarus. E-mail: zoo@bsu.by
\end{abstract}

During aphidological research in 2007 two species of the genus Aphis L., Aphis subviridis (Börner, 1940) and A. polygonata (Nevsky, 1929), have been registered for the first time on the territory of Byelorussia. Aphids on plants have been transferred to a laboratory, where adult sexuales appeared in September. Since the morphological descriptions of male and oviparous females of $A$. subviridis and male of $A$. polygonata were absent, the detailed ones are given in the article.

All measurements (always in $\mu \mathrm{m}$ ), number of hairs, rhinaria, etc., and indexes are presented by extreme variants and in brackets by arithmetical mean, for example 254-325 (287). Microscope slides are stored in collections of the Zoological Institute of RAS (St. Petersburg). In the description of hitherto unknown morphs of Aphis subviridis, oviparous female is examined in more detail and for male differences from oviparous female are specified only.

Aphis subviridis (Börner, 1940)

(Table, Figs 1-12)

Material. Byelorussia, Minsk Prov.: 18.IX.2007, Minsk Distr., Sosny forestry, sandy edge of forest road, on root collar of Potentilla argentea L., then in culture, 3 male, sample no.11-07, 26.IX.2007, 11 oviparous females, sample no.12-07, 26.IX.2007, N.V. Leshchinskaya.

Aphis subviridis has been described by Börner in his work 'Neue Blattläuse aus Mitteleurope' (1940) as Cerosipha subviridis from apterous viviparous females from Potentilla argentea L. Later the species has been registered in Poland
(Szelegiewicz, 1966), Ukraine (Bozhko, 1976), Mediterranean France (Leclant, 1978) and Latvia (Rupais, 1989). In autumn 2007 apterous viviparous females of $A$. subviridis was collected on root collar of $P$. argentea in one geographic point near Minsk. Males and oviparous females appeared in laboratory condition in September.

Oviparous female. Elliptic or elongated-elliptic, body 1.6-2.1 (1.8) times as long as wide. When alive, yellow-green, with dark apices of antennal segments, pale yellow legs and yellowgreen siphunculi and cauda. Cleared specimens with dark brown frons, with brown 5th and 6th antennal segments, siphunculi, cauda, anal and subgenital plates; with light brown head (except of frons), 1st-5th antennal segments (except for base of 3rd and apex of 5th segments), 3rd and 4th rostral segments, legs and peritremes on all segments, with very light brown band on abdominal tergites VIII. Dorsal surface of thorax not sclerotized. Abdominal dorsum with very light brown band on abdominal tergites VIII only. Surface of head and pronotum reticulate (contour of cells on head formed by strongly smoothedout, flat spinules, on pronotum by wrinkles), of meso- and metanotum and abdominal tergites I-VI distinctly wrinkled, of tergite VII-VIII with the rows of small dentiform spinules which partially fused and forming long scales; surface of ventral side of pro- and mesothorax wrinkled with some pointed spinules, of ventral side of metathorax and abdomen with long rows of small dentiform spinules frequently forming strongly stretched 


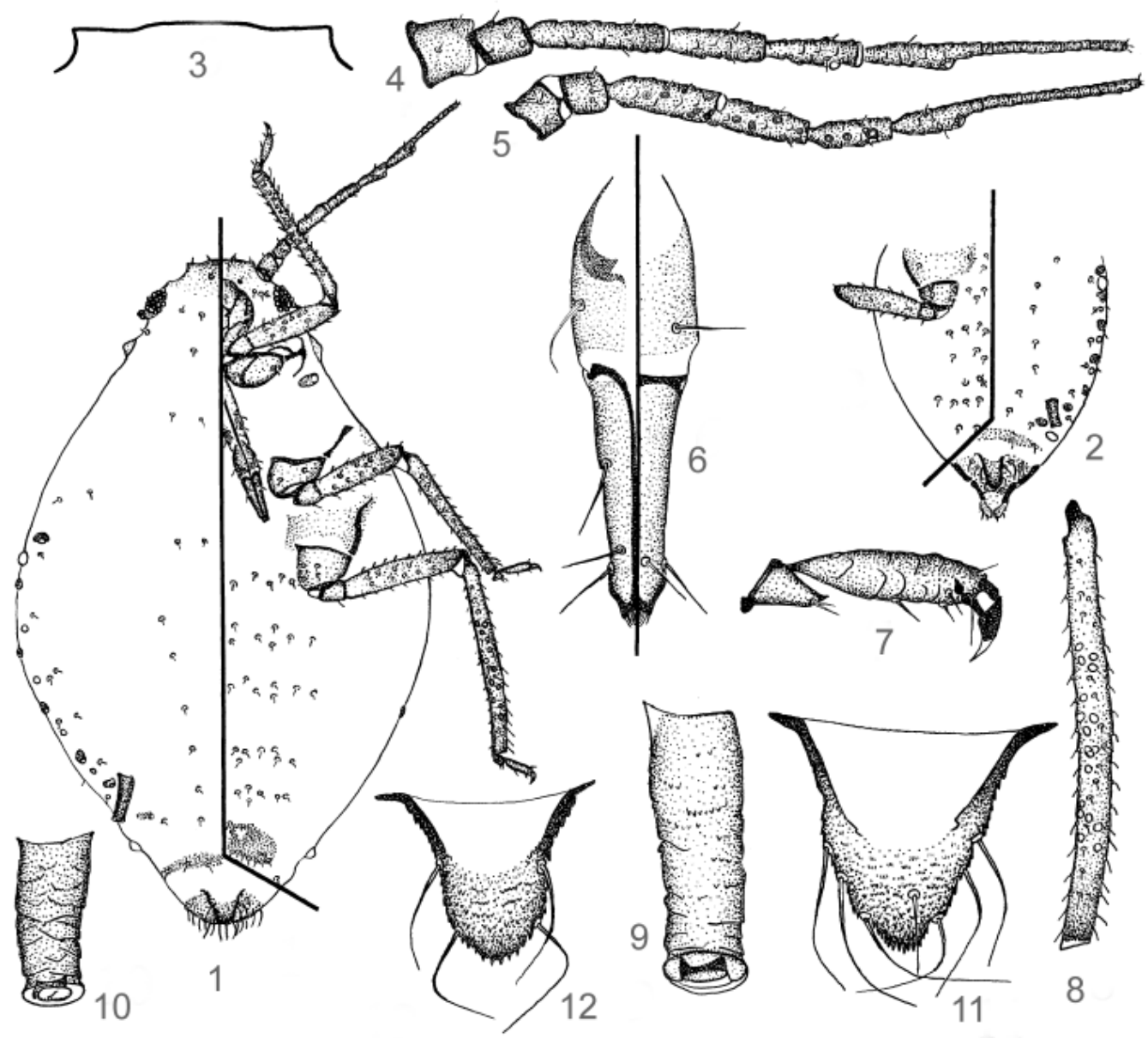

Figs 1-12. Aphis subviridis. 1, body of oviparous female; 2 , abdomen of male; $\mathbf{3}$, front of oviparous female; $\mathbf{4 - 5}$, antenna (4, of oviparous female; 5 , of male); $\mathbf{6}$, ultimate segment of rostrum of oviparous female; 7 , hind tarsus of oviparous female; $\mathbf{8}$, hind tibia of oviparous female; 9-10, siphunculi (9, of oviparous female; 10 , of male); 11-12, cauda (11, of oviparous female; 12, of male).

cells. Hairs on dorsal and ventral surface of thorax and abdomen short, blunt, almost rod-shaped, or very weakly capitate; longest dorsal, marginal and ventral hairs on abdominal tergite III 10-13 (11), 10-13 (12) and 10-18 (13) $\mu \mathrm{m}$ long, 0.570.82 (0.67), 0.62-0.91 (0.71) and 0.57-1.27 (0.79) times as long as articular diameter of 3rd antennal segment, respectively; marginal hairs 1, 2, 1-3, 2, 2-3, 2 and $0-1$ on each side of abdominal segments I-VII; abdominal tergite III with 1-2 (1.9) dorsal hairs; tergite VI with 2 hairs between siphunculi; tergite VIII with 8-12 (9.6) hairs, 14-20 (17) $\mu \mathrm{m}$ long, 0.85-1.45 (1.03) times as long as articular diameter of 3rd antennal segment. Light marginal tubercles always present on prothorax, I and VII abdominal segments, almost always on II-V abdominal segments (one marginal tubercle absent on segment II in $9 \%$ of specimens, on segment III in $18 \%$ of specimens and on segment $\mathrm{V}$ in $27 \%$ of specimens) and marginal tubercles present also on segment VI in $45 \%$ of specimens (2 tubercles in $9 \%$ of specimens); marginal tubercles protuberant or strongly protuberant, semicircular or nippleshaped, on prothorax and abdominal segment VII large, on segments I-IV smaller, diameter of tubercles 1.0-3.3 times the height of tubercles. Head without traces of epicranial coronal suture. Frontal tubercles low; median tubercle surpassing the level of antennal tubercles. Occipital and frontal hairs short, blunt, almost rod-shaped, longest occipital and frontal hairs 10-13 (11) $\mu \mathrm{m}$ long, 0.57-0.77 (0.66) and 0.57-0.83 (0.70) times as long as articular diameter of 3rd antennal segment, respectively. Antennae 6-segmented in 46\% of specimens, one (in $27 \%$ of specimens) or both antennae (in $27 \%$ of specimens) 5 -segmented due 
Table. Biometric data for Aphis subviridis (Börner, 1940) and A. polygonata (Nevsky, 1929).

\begin{tabular}{|c|c|c|c|c|c|}
\hline & & & \multicolumn{2}{|c|}{$\begin{array}{c}\text { Aphis } \\
\text { subviridis }\end{array}$} & $\begin{array}{c}\text { Aphis } \\
\text { polygonata }\end{array}$ \\
\hline \multicolumn{3}{|l|}{ Morph } & $\begin{array}{c}\text { Oviparous } \\
\text { females }\end{array}$ & Males & Males \\
\hline \multicolumn{3}{|c|}{ Number of samples / specimens } & $1 / 11$ & $1 / 3$ & $1 / 2$ \\
\hline \multicolumn{3}{|l|}{ Length of body } & $\begin{array}{c}1259-1726 \\
(1462)\end{array}$ & $\begin{array}{c}1147-1218 \\
(1194)\end{array}$ & $\begin{array}{c}1173-1208 \\
(1193)\end{array}$ \\
\hline \multicolumn{3}{|c|}{ Length of antennae } & $\begin{array}{c}583-680 \\
(638)\end{array}$ & $\begin{array}{c}\text { 583-608 } \\
(594)\end{array}$ & $\begin{array}{c}936-980 \\
(959)\end{array}$ \\
\hline \multicolumn{3}{|c|}{ Length of antennae / length of body } & $\begin{array}{c}0.38-0.50 \\
(0.44)\end{array}$ & $\begin{array}{c}0.48-0.52 \\
(0.50)\end{array}$ & $\begin{array}{c}0.79-0.81 \\
(0.80)\end{array}$ \\
\hline \multirow{2}{*}{ Hind femura } & \multicolumn{2}{|c|}{ length } & $\begin{array}{c}254-325 \\
(287)\end{array}$ & $\begin{array}{c}233-249 \\
(240)\end{array}$ & $\begin{array}{c}315-335 \\
(324)\end{array}$ \\
\hline & \multicolumn{2}{|c|}{ length / head width across the compound eyes } & $\begin{array}{c}0.74-0.84 \\
(0.79)\end{array}$ & $\begin{array}{c}0.65-0.72 \\
(0.69)\end{array}$ & $\begin{array}{c}0.98-1.01 \\
(1.00)\end{array}$ \\
\hline \multicolumn{3}{|c|}{ Head width across the compound eyes } & $\begin{array}{l}344-387 \\
(361)\end{array}$ & $\begin{array}{l}343-360 \\
(350)\end{array}$ & 332 \\
\hline \multicolumn{3}{|c|}{ Number of marginal tubercles } & $\begin{array}{c}12-15 \\
(14)\end{array}$ & $\begin{array}{c}9-14 \\
(11.3) \\
\end{array}$ & 6 \\
\hline \multirow{3}{*}{$\begin{array}{l}\text { 6th antennal } \\
\text { segment }\end{array}$} & \multicolumn{2}{|c|}{ length of base } & $\begin{array}{c}84-96 \\
(90)\end{array}$ & $\begin{array}{l}71-88 \\
(77)\end{array}$ & $\begin{array}{c}76-87 \\
(82)\end{array}$ \\
\hline & \multicolumn{2}{|c|}{ length of processus terminalis } & $\begin{array}{c}144-172 \\
(160)\end{array}$ & $\begin{array}{c}131-159 \\
(143)\end{array}$ & $\begin{array}{c}174-181 \\
(178)\end{array}$ \\
\hline & \multicolumn{2}{|c|}{ length of processsus terminalis / length of base } & $\begin{array}{c}1.68-1.91 \\
(1.78)\end{array}$ & $\begin{array}{c}1.63-2.25 \\
(1.88)\end{array}$ & $\begin{array}{c}2.01-2.30 \\
(2.17\end{array}$ \\
\hline \multirow{4}{*}{$\begin{array}{l}\text { Ultimate rostral } \\
\text { segment }\end{array}$} & \multicolumn{2}{|l|}{ lenght } & $\begin{array}{l}104-121 \\
(114)\end{array}$ & $\begin{array}{l}97-101 \\
(99)\end{array}$ & 89 \\
\hline & \multirow{3}{*}{ length / } & head width across the compound eyes & $\begin{array}{c}0.30-0.34 \\
(0.32)\end{array}$ & $\begin{array}{c}0.27-0.29 \\
(0.28)\end{array}$ & 0.27 \\
\hline & & length of 2nd segment of hind tarsus & $\begin{array}{c}1.20-1.38 \\
(1.32)\end{array}$ & $\begin{array}{c}1.28-1.36 \\
(1.32)\end{array}$ & $\begin{array}{c}0.89-0.96 \\
(0.91)\end{array}$ \\
\hline & & length of base of 6th antennal segment & $\begin{array}{c}1.17-1.38 \\
(1.27) \\
\end{array}$ & $\begin{array}{c}1.11-1.43 \\
(1.30) \\
\end{array}$ & $\begin{array}{c}1.01-1.17 \\
(1.08) \\
\end{array}$ \\
\hline \multirow{3}{*}{$\begin{array}{l}\text { 2nd segment of } \\
\text { hind tarsus }\end{array}$} & \multicolumn{2}{|l|}{ lenght } & $\begin{array}{c}82-89 \\
(86)\end{array}$ & $\begin{array}{l}73-77 \\
(75)\end{array}$ & $\begin{array}{l}92-100 \\
(97)\end{array}$ \\
\hline & \multirow{2}{*}{ length / } & head width across the compound eyes & $\begin{array}{c}0.23-0.25 \\
(0.24) \\
\end{array}$ & $\begin{array}{c}0.21-0.22 \\
(0.22) \\
\end{array}$ & $\begin{array}{c}0.29-0.30 \\
(0.30) \\
\end{array}$ \\
\hline & & length of base of 6th antennal segment & $\begin{array}{c}0.92-1.00 \\
(0.96)\end{array}$ & $\begin{array}{c}0.95-1.07 \\
(1.01)\end{array}$ & $\begin{array}{c}1.11-1.30 \\
(1.19)\end{array}$ \\
\hline \multirow{2}{*}{ Siphunculi } & length & & $\begin{array}{l}83-124 \\
(109)\end{array}$ & $\begin{array}{l}73-81 \\
(77)\end{array}$ & $\begin{array}{c}56-63 \\
(59)\end{array}$ \\
\hline & \multicolumn{2}{|c|}{ length / width of siphunculi at half length } & $\begin{array}{c}2.20-3.36 \\
(2.91)\end{array}$ & $\begin{array}{c}2.40-2.78 \\
(2.57)\end{array}$ & $\begin{array}{c}1.64-1.69 \\
(1.67)\end{array}$ \\
\hline \multicolumn{3}{|l|}{ Length of cauda } & $\begin{array}{l}96-106 \\
(102)\end{array}$ & 78 & $\begin{array}{l}89-94 \\
(91)\end{array}$ \\
\hline \multicolumn{3}{|c|}{ Length of siphunculi / length of cauda } & $\begin{array}{c}0.85-1.18 \\
(1.05)\end{array}$ & $\begin{array}{c}0.94-1.03 \\
(0.99)\end{array}$ & $\begin{array}{c}0.62-0.68 \\
(0.64)\end{array}$ \\
\hline
\end{tabular}


to more or less complete fusing of 3rd and 4th segments, without secondary rhinaria. Hairs on antennae rod-shaped or very weakly capitate; longest hair on 3rd segment 9-10 (10) $\mu \mathrm{m}$ long, 0.50$0.73(0.60)$ times as long as articular diameter of the segment; basal part of 6th antennal segment with 2-3 (2.9) hairs, longest hair 0.73-0.91 (0.80) times as long as articular diameter of basal part of the segment. Rostrum reaching metathorax or abdominal segment II. Ultimate rostral segment elongate wedge-shaped with slightly concave sides, 2.21-2.82 (2.50) times as long as its basal width, with 2 accessory hairs. Hind femora and hind tibiae $0.18-0.21(0.20)$ and $0.31-0.36(0.33)$ times as long as body, respectively. Hairs on legs rod-shaped, very weakly capitate or pointed; ventral hair on hind trochanter 0.27-0.53 (0.35) times as long as basal diameter of hind femur; longest dorsal, ventral and dorso-apical hairs on hind femur 13-15 (14), 24-29 (25) and 10-13 (12) $\mu \mathrm{m}$ long, respectively; longest dorsal hair on hind tibia 33-53 (38) $\mu \mathrm{m}$ long, 0.72-1.50 (1.06) times as long as mid-diameter of the latter. Hind tibia with 14-32 (22.0) rounded pheromone plates. Chaetotaxy of first tarsal segments 3, 3, 2 and only sometimes one fore or middle tarsus with 2 hairs. 2nd segment of hind tarsus 4.00-4.38 (4.22) times as long as its maximum width, with 1-2 (1.3) ventral hairs in addition to the three apical pairs, dorsal hairs absent. Siphunculi faintly narrowed to apex, almost cylindrical, imbricate, with small flanges, 2.50-3.77 (3.13) times as long as their basal width, 0.06-0.08 (0.08) times as long as body and 0.50-0.98 (0.75) times as long as 3rd antennal segment. Subgenital plate oval, with 16-20 (18.1) hairs on anterior half and 13-20 (15.9) blunt, rod-shaped or pointed hairs along hind margin. Hairs on anal plate finely pointed. Cauda triangular, elongated-triangular or almost short tongue-shaped, 0.79-1.02 (0.90) times as long as its basal width, with 8-10 (8.8) long, finely pointed or pointed hairs.

Measurements. Body $1680 \times 1066$; antennae 680: III $139 \times 25$, IV 91, V 83, VI 94+167; hind femur 325; hind tibia 518; siphunculus $124 \times 38$; cauda $106 \times 134$ (at base) $\times 104$ (before base).

Male. Apterous. Elongated-elliptic, body 2.0-2.1 times as long as wide. When alive, yellow-green, with dark apices of antennae, brown siphunculi with dark apices and brown cauda. Cleared specimens with dark brown head and antennae, with brown apices of tibia. Surface of abdominal tergite VI with the rows of small dentiform spinules which partially fused and forming long scales. Hairs on dorsal and ventral surface of thorax and abdomen short, blunt or, very rarely, pointed; longest dorsal, marginal and ventral hairs on abdominal tergite III 10, 8-11 (9) and 10-15 (13) $\mu \mathrm{m}$ long, 0.67-0.73 (0.71), 0.55-0.82 (0.65) and 0.73-1.09 (0.92) times as long as articular diameter of 3rd antennal segment, respectively; marginal hairs 1, 1-2, 1-2, 2, 2, 1-2 and 1-3 on each side of abdominal segments I-VII; tergite VIII with 2-3 (2.3) hairs, 14-19 (16) $\mu \mathrm{m}$ long, 0.921.67 (1.16) times as long as articular diameter of 3rd antennal segment. Light marginal tubercles always present on prothorax, abdominal segments I and VII, 2 marginal tubercles also present on abdominal segment II in 2 of 3 specimens, marginal tubercles present on segment III in all specimens ( 2 tubercles in 1 specimen), on abdominal segment IV in 2 of 3 specimens ( 2 tubercles in 1 specimen), and one tubercle present on segment $\mathrm{V}$ in all specimens and on VI in 2 specimens. Frontal tubercles not marked. Longest occipital and frontal hairs 0.67-1.11 (0.84) and 0.67-0.89 (0.77) times as long as articular diameter of 3rd antennal segment, respectively. Antennae 6-segmented, with incomplete separation of 3rd and 4th segments, or 5-segmented. Secondary rhinaria 9-24 (14.3) on 3rd antennal segment, 9-16 (11.5) on 4th segment, 2-6 (4.2) on 5th segment, rounded or oval, very weakly projecting, with external contour 6.3-20.0 times as long as high. Hairs on antennae blunt or pointed; longest hair on 3rd segment 0.64-0.78 (0.70) times as long as articular diameter of the segment; longest hair on basal part of 6th antennal segment 0.67-0.78 (0.72) times as long as articular diameter of basal part of the segment. Ultimate rostral segment wedge-shaped with straight or slightly convex sides, 1.70-2.00 (1.85) times as long as its basal width. Hairs on legs blunt or pointed; ventral hair on hind trochanter $0.29-0.35$ (0.32) times as long as basal diameter of hind femur; longest dorsal, ventral and dorso-apical hairs on hind femur 10,11-13 (12) and 6-10 (8) $\mu \mathrm{m}$ long, respectively; longest dorsal hair on hind tibia 30-38 (33) $\mu \mathrm{m}$ long, 1.04-1.25 (1.15) times as long as mid-diameter of the latter. 2nd segment of hind tarsus 3.59-4.21 (3.78) times as long as its maximum width. Siphunculi almost cylindrical, 2.06-3.94 (2.71) times as long as their basal width, 0.06-0.07 (0.06) times as long as body and 0.38-0.71 (0.56) times as long as 3rd antennal segment. Cauda triangular, with rounded apex and slight constriction, 0.82-1.15 (0.93) times as long as its basal width, with 4-6 (5.0) long, finely pointed or pointed hairs.

Measurements. Body $1147 \times 579$; antennae 599: III $121 \times 33$, IV 80 , V 78, VI 71+159; hind femur 233; hind tibia 406; siphunculus $73 \times 29$; cauda $78 \times 95$ (at base) $\times 82$ (before base) .

\section{Aphis polygonata (Nevsky, 1929)}

(Table, Figs 13-19)

Material. Byelorussia, Minsk: viviparous females, ruderal vegetation, on stems of Polygonum arenastrum Boreau, then in culture, 2 male, sample no. 9-07, 17.IX.2007, N.V. Leshchinskaya. 


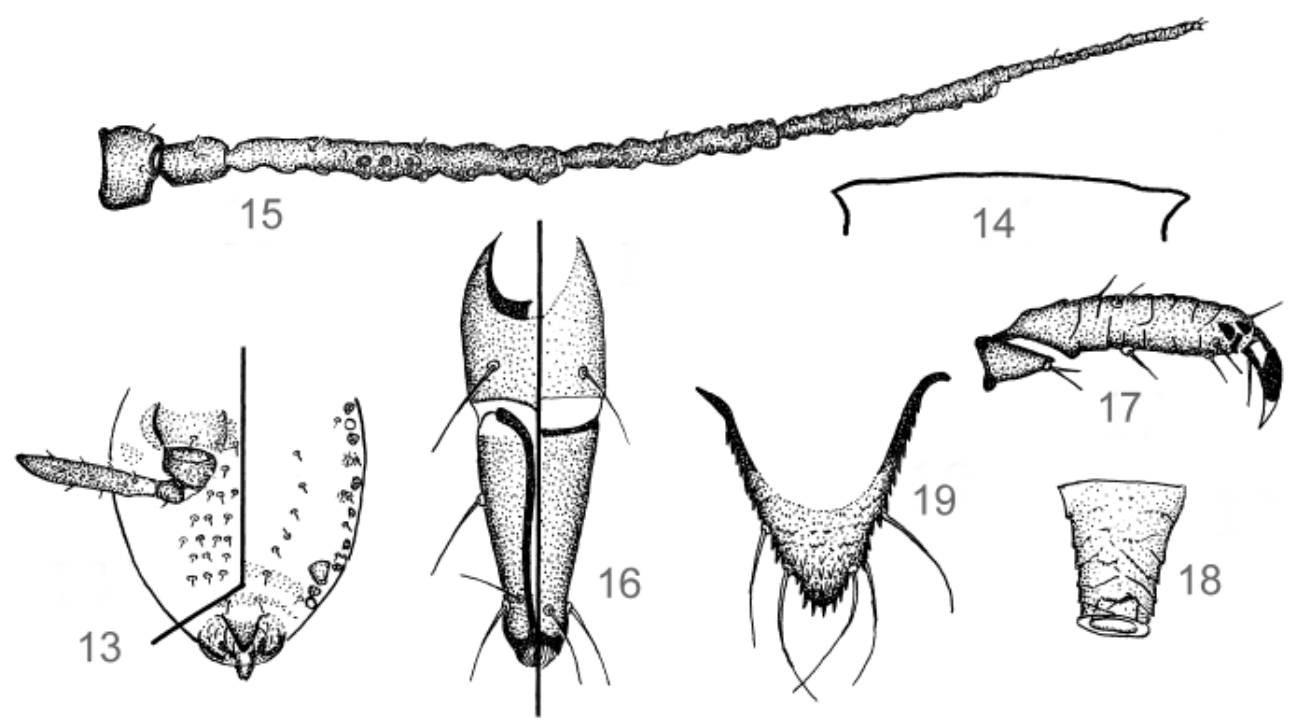

Figs 13-19. Aphis polygonata, male. 13, abdomen; 14, front; 15, antenna; 16, ultimate segment of rostrum; 17, hind tarsus; 18, siphunculi; 19, cauda.

Aphis polygonata has been described by Nevsky in 1929 as Pergandeida polygonata from apterous and alate viviparous females collected in Uzbekistan (Tashkent, Samarkand) from Polygonum aviculare L. s.l., Polygonum argyrocoleon Steud.ex G.Kunze and Polygonum equlsetiforme Sibth.et Sm. Hille Ris Lambers in 1931 described Doralis avicularis from apterous and alate viviparous females collected in Holland (Lith), Switzerland (Züruch) and Italy (Merano). Börner (1952) considered that D. avicularis H.R.L. is a synonym of Aphis polygonata (Nevsky, 1929) (as Cerosipha polygonata (Nevsky, 1929)) without any comment, but finally the synonymy have been established by Remaudière and Remaudière (1997) only. In their work registration of alate males from Iran is mentioned, but their description is absent.

To present day A. polygonata was registered in Europe, Middle East, Central Asia, North America (USA: California) (Blackman, Eastop, 2006) and also in Western Siberia (Ivanovskaja, 1977). In Byelorussia the species were collected in 4 geographical points: no. 97-050 Minsk: viviparous females, Central botany gardens of National academy of Science of Belarus, ruderal vegetation, 13.VII.1997, on stems of Polygonum arenastrum Boreau (S.V. Buga); no. 00-805 Gomel Prov.: viviparous females, Gomel, valley of Sozh river, ruderal vegetation, 5.VIII.2000, on stems of Polygonum arenastrum Boreau (S.V. Buga); no. 02-200 Vitebsk Prov.: viviparous females, Rossony, ruderal vegetation, 1.VII.2007, on stems of Polygonum arenastrum Boreau (S.V. Buga); no. 9-07 Minsk: viviparous females, ruderal vegetation, VIII.2007, on stems of Polygonum arenastrum Boreau (N.V. Leshchinskaya), then in laboratory conditions, where males appeared in September.

Male. Elliptic, body 2.0 times as long as wide. When alive, almost black, antennae light with dark apices of segments, femora and tarsi black, tibia light, siphunculi and cauda dirty olivecoloured. Cleared specimens with dark brown head, thorax, 1st-2nd antennal segment, 3rd and 4th rostral segments, coxae, femora (except for their bases), apices of tibia, anal plates and cauda, with brown 3rd-6th antennal segments (except for base of 3rd segment), sclerites at bases of hind coxae, tarsi, intersegmental plates, marginal maculae and peritremes on abdominal segments; with light brown base of 3rd antennal segment, bases of femora, tibia (except for their bases), apices), bands on abdominal tergites VII-VIII and siphunculi. Abdominal dorsum with light brown marginal maculae on segments II-IV, thin bands on abdominal tergites VII-VIII and peritremes on abdominal segments I-VII. Surface of head and thorax smooth, of abdominal tergites I-VI reticulate (contour of cells formed by thick, irregular line), of tergites VII-VIII with the rows of pointed or smoothed-out spinules which partially fused and forming long scales; surface of ventral side of abdomen with long rows of small pointed spinules frequently forming strongly stretched cells. Hairs on dorsal surface of thorax and abdomen blunt 
or pointed, on ventral surface pointed or finely pointed; longest dorsal, marginal and ventral hairs on abdominal tergite III 15, 16-18 (17) and 23-25 (24) $\mu \mathrm{m}$ long, 0.86, 0.93-1.00 (0.96) and 1.291.43 (1.36) times as long as articular diameter of 3rd antennal segment, respectively; marginal hairs 1-3, 2-3, 2, 1-2, 2, 2 and 1 on each side of abdominal segments I-VII; abdominal tergite III with 1-2 dorsal hairs; tergite VI with 2 hairs between siphunculi; tergite VIII with 2 hairs, 20 $\mu \mathrm{m}$ long, 1.14 times as long as articular diameter of 3rd antennal segment. Very light brown marginal tubercles present only on prothorax, I and VII abdominal segments, they are strongly protuberant, nipple-shaped, not large, diameter of tubercles 0.5-1.4 times the height of tubercles. Head without traces of epicranial coronal suture. Frontal tubercles almost not marked; median tubercle surpassing the level of antennal tubercles. Occipital and frontal hairs blunt or pointed, longest occipital and frontal hairs 12, 18-19 (18) $\mu \mathrm{m}$ long, 0.71 and 1.00-1.07 (1.04) times as long as articular diameter of 3rd antennal segment, respectively. Antennae 6-segmented. Secondary rhinaria 18-23 (20.8) on 3rd antennal segment, 11-15 (13.0) on 4th segment, 5-10 (7.0) on 5th segment; secondary rhinaria rounded or oval, weakly projecting, with external contour 2.0-5.8 times as long as high. Hairs on antennae pointed; longest hair on 3rd segment 13-15 (14) $\mu \mathrm{m}$ long, 0.71$0.86(0.79)$ times as long as articular diameter of the segment; basal part of 6th antennal segment with 1-2 (1.5) hairs, longest hair 0.60-0.80 (0.69) times as long as articular diameter of basal part of the segment. Rostrum reaching metathorax. Ultimate rostral segment wedge, 1.75-1.94 (1.85) times as long as its basal width, with 2 accessory hairs. Hind femora and hind tibiae 0.26-0.28 (0.27) and 0.49-0.50 (0.49) times as long as body, respectively. Hairs on legs pointed or, rarely, finly pointed; ventral hair on hind trochanter 0.69-0.86 (0.75) times as long as basal diameter of hind femur; longest dorsal, ventral and dorso-apical hairs on hind femur 13-18 (16), 20-25 (22) and 11-13 (12) $\mu \mathrm{m}$ long, respectively; longest dorsal hair on hind tibia 25-33 (28) $\mu \mathrm{m}$ long, 0.67-0.86 (0.75) times as long as mid-diameter of the later. Chaetotaxy of first tarsal segments $3,3,2$. 2nd segment of hind tarsus 4.29-4.88 (4.59) times as long as its maximum width, with 1-2 (1.5) ventral and $0-1(0.75)$ dorsal hairs in addition to the three apical pairs. Siphunculi short, narrowed to apex, weakly conical, imbricate, with small flanges, 1.28-1.69 (1.43) times as long as their basal width, 0.05 times as long as body and 0.20-0.22 (0.21) times as long as 3rd antennal segment. Hairs on anal plate finely pointed. Cauda triangular, 0.88 times as long as its basal width, with 4-6 (5.0) finely pointed hairs.

Measurements. Body $1178 \times 599$, fore wing 1736, antennae 936: III $281 \times 29$, IV 180 , V 114, VI $76+174$; hind femur 335 , hind tibia 589 , siphunculus $58 \times 35$; cauda $94 \times 106$ (at base) $\times 82$ (before base).

\section{Acknowledgements}

The authors are grateful to G.J. Zubkevich and T.A. Sautkina (Byelorussian State University, Minsk) for their help in the process of determining of host plants of aphids.

\section{References}

Börner, C. 1940. Neue Blattläuse aus Mitteleurope. Naumburg. $4 \mathrm{p}$.

Börner, C. 1952. Europae centralis Aphides. Mitt. Thüring. botanisch. Ges., Beiheft 3(1-2): 1-484.

Bozhko, M.P. 1976. Tli kormovykh rastenij [Aphids of the nutritious plants]. Kharkov: Vishtsha shkola, Kharkov Gos. Univ. 135 p. (In Russian).

Ivanovskaja, O.I. 1977. Tli Zapadnoj Sibiri. Semejstvo Aphididae [Aphids of the Western Siberia. Family Aphididae]. Novosibirsk: Nauka. 328 p. (In Russian).

Leclant, F. 1978. Étude bioécologique des Aphides de la région méditerranéenne. Implications Agronomiques. Thèse de Doctorat d'Etat., Acad. Montpelier, Univ. Sciences Techniq., Languedoc. 318 p.

Nevsky, V.P. 1929. Tli Srednej Asii [The plant lice of Middle Asia]. Tr. Uzbek. Opytn. St. Zashch. Rast., 16: 1-425. (In Russian).

Remaudière, G. \& Remaudière, M. 1997. Catalogue of the word's Aphididae. Paris: INRA Editions. $474 \mathrm{p}$.

Rupais, A.A. 1989. Tli (Aphidodea) Latvii [The aphids (Aphidodea) of Latvia]. Riga: Zinatne. 331 p. (In Russian).

Szelegiewicz, H. 1966. Ergänzungen zur Blattlausfauna (Homoptera: Aphididae) Polens. Fragm. Faun., 12(25): 429-455.

Received 10 May 2008, accepted 10 June 2008. 